\title{
STEM Collaboration Assessment Leading to Curriculum Changes and Greater Long-Term STEM Engagement
}

\section{Dr. Ronald W. Welch, The Citadel}

Ron Welch (P.E.) received his B.S. degree in Engineering Mechanics from the United States Military Academy in 1982. He received his M.S. and Ph.D. degrees in Civil Engineering from the University of Illinois, Champaign-Urbana in 1990 and 1999, respectively. He became the Dean of Engineering at The Citadel on 1 July 2011. Prior to his current position, he was the Department Head of Civil Engineering at The University of Texas at Tyler from Jan 2007 to June 2011 as well as served in the Corps of Engineers for over 24 years including eleven years on the faculty at the United States Military Academy. 


\title{
STEM Collaboration Assessment Leading to Curriculum Changes and Greater Long-Term STEM Engagement?
}

\begin{abstract}
Gifted Fourth and Fifth Grade students from Richland School District 2 conduct a field study

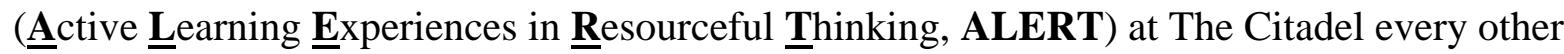
year. The focus is for their students from 19 elementary schools who are part of a district-wide gifted and talented pullout program to experience STEM disciplines in a college environment to not only inform the future mathematics and science classes they have and will have, but also to begin the discussion on the importance of going to college and follow-on careers, especially in STEM disciplines. The School of Engineering and Science and Mathematics work together to provide four distinct one hour blocks of activities and interaction with discussion of how devices work (theory). The key focus is engineering and each student group of 25 students see two one hour blocks on engineering (civil and electrical). The students complete a reflection on the daylong experience and the teachers incorporate pictures of the activities the students experienced into future mathematics and science lesson plans to complete the learning circle by tying mathematics/science problems to their experiences. Many of these students decide to apply for academic magnet middle schools focused on STEM based on the success of the $4^{\text {th }}$ and $5^{\text {th }}$ grade integrated lesson/field trip curriculum to The Citadel. Assessment of curriculum changes based on the field trip, student reflective essays, and future attendance at middle and high school STEM magnets will demonstrate the importance of collaboration between universities and elementary and middle school programs (especially STEM focused programs) on engagement with STEM disciplines in the future.
\end{abstract}

\section{Introduction}

Everywhere you read there are discussions about the importance to increase the number of students entering Science, Technology, Engineering, and Mathematics (STEM) fields out of college. However, upon closer reflection, the focus today is to increase the number of students entering STEM fields out of high school through direct employment as technicians or going to college in a STEM field. High schools around the country have replaced or enhanced their offerings in the areas that used to cover shop and home economics. We see high schools with STEM programs that are focused on drafting, electronics, and college STEM preparation. ${ }^{1}$

Success in STEM focused high school programs relies on students entering with a desire to study and/or enter STEM fields. Therefore, numerous states have elementary and middle schools that are either becoming magnet (focused) schools or are designated a STEM school. In South Carolina, a number of elementary and middle schools have been designated a STEM school. These schools seek out annual field trips to allow their students to have firsthand STEM 
experiences such as laboratory experiences within college level courses, aquariums, architectural firms, research labs, and manufacturing companies to mention a few.

Gifted and talented Fourth and Fifth Grade students from Richland School District 2 schools have been conducting a field study $(\mathbf{A L E R T})^{2}$ at The Citadel every other year. Recently, the off year visit is with an architectural firm at the school and a visit to the firm on a Saturday. The focus of each visit is for their students from 19 elementary schools who are part of a district-wide gifted and talented pullout program to experience STEM disciplines in a college/professional environment to not only inform the future mathematics and science lessons they have that semester or will have the following year, but also to initiate the discussion about STEM careers and the importance of going to college to be qualified for entry level positions in certain STEM careers, especially in professional disciplines such as engineering and architectural. This paper will discuss the STEM activities at The Citadel and at the ALERT district-wide gifted and talented pullout programs, the results, concerns, and conclusions.

\section{Activities at The Citadel}

The School of Engineering and the School of Science and Mathematics work together to provide four distinct one hour blocks of activities. Approximately 100 elementary students arrive the day of a visit and are broken into four groups of about 25 students. Not only is there an activity and interaction with faculty and college students, but also a discussion of how each of the devices works (some theory with a focus on mathematics and science fundamentals). A key focus for the visit is engineering and each student group of 25 students see two one hour blocks on engineering (civil and electrical). The other two hour blocks could be Mathematics, Chemistry, Biology, Physics, or a campus tour. The lack of consistency outside of the two one hour engineering blocks is due to some departments not being able to participate during each of the six visits during the month. Each student must complete a reflection on the day-long experience which not only helps focus their elementary mathematics and science teachers on future activities, but also serve to thank the faculty and students at The Citadel.

"Dear Professors, Thanks for letting us come to the Citadel for free!

ALERT had fantastic time learning about trebuchets, robots, more math, etc. I have to say my favorite was the robot sections! I play baseball so watching a robot hit the baseball and run the bases was quite exciting. I had the best time ever! Thanks again..."3

Biology. During the biology activity hour, the $4^{\text {th }}$ and $5^{\text {th }}$ graders investigated the similarities in the development of embryos of various species to provide evidence for The Theory of

Evolution. This is always a little tricky since many of these students have never heard anything about evolution prior to the visit to the campus. The faculty began with a quick interactive tutorial on the basic principles of DNA, mutation, and natural selection. They then showed a video clip from the PBS NOVA film "The Miracle of Life"4 that shows a living human embryo 
pass through various stages of development; the students are fascinated to see that they all developed in fluid-filled amnions, that they all once had a tail and webbed fingers and primitive gill slits. Next they worked as a group on an interactive activity from NOVA called "Guess the Embryo" 5 that allows them to see how similar various vertebrate embryos appear in early stages of development. Finally they individually worked on a project where they attempt to align images of embryos according to species and stage of development (Figures 1-3). At the end of the last activity they were told that the reason it is so hard to align the images correctly is because all these species came from a common ancestral species that had DNA instructions for early development that all the different vertebrate species still share, and that what makes the species different are the different mutations that the various populations acquired over time.

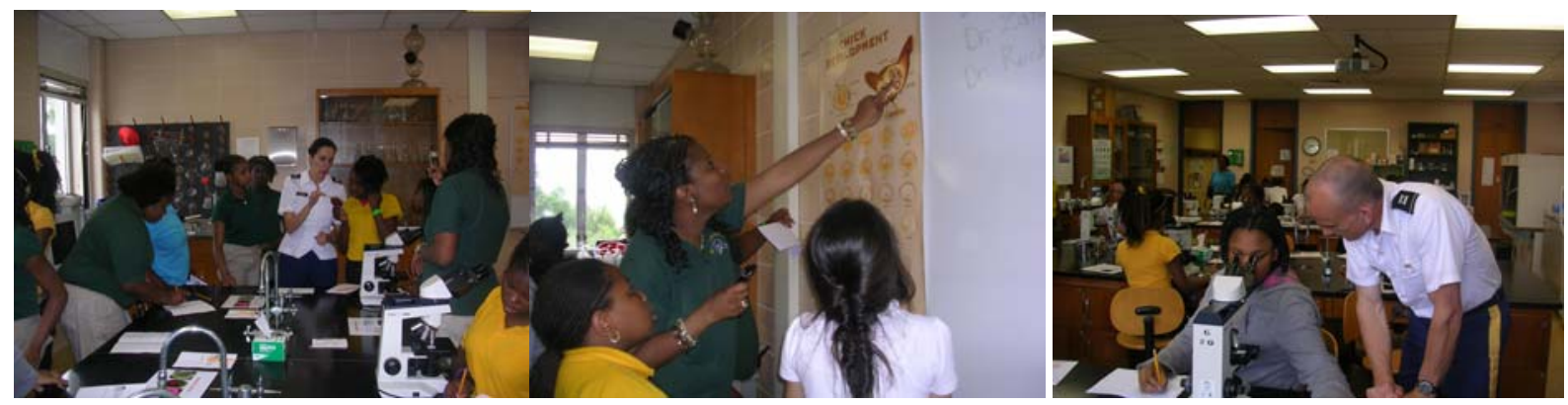

Figures 1-3. Studying embryos.

Chemistry. During the Chemistry activity hour, the $4^{\text {th }}$ and $5^{\text {th }}$ graders focused on energy and investigated the distinctive flame tests of metals. It is related to the return of the excited electron to the ground state, the distinctive color to the element present and to the colors present in fireworks. They did some flame tests as a group and then they did flame tests of unknown substances in small groups and worked to identify them. They also combusted a gummy bear (sugar) in a high oxygen environment with potassium ions present which produce a strong lavender color flame (i.e., the Dancing Gummy Bear). ${ }^{6}$

Mathematics. During the mathematics activity hour, the $4^{\text {th }}$ and $5^{\text {th }}$ graders practiced (mathematical) problem-solving skills using a variety of real-life situations. Examples: 1) It takes a lumberjack 16 seconds to cut a thick log into 5 pieces. Cutting at the same speed, how long does it take to cut the log into 10 pieces? 2) Farmer has a mixed herd of pigs and chickens. The herd has 26 heads and 70 legs. How many pigs and how many chickens? ${ }^{7}$ The process moved the students toward using algebra without them knowing it.

Physics. During the Physics activity hour, the $4^{\text {th }}$ and $5^{\text {th }}$ graders investigated the basic principles which enable rocket flight. They discussed inertia by observing motion on an air track, the forces that are needed to change the motion of an object by observing the effect of a spring on an air track boat, and Newton's Third Law of Motion (for every action there is an equal and opposite reaction) through observation of the reaction of a hose to exhaust flow from a shop vacuum. These activities demonstrate and help the students understand the theory behind a rocket launch 
as well as the safety issues needed to successfully launch a rocket. The students finish the hour by covering the procedures to safely launch a model rocket and then do so under the supervision of faculty and college students (Figure 4). As an incentive, the students who landed their rocket in the target area were allowed to take their model home. ${ }^{8}$

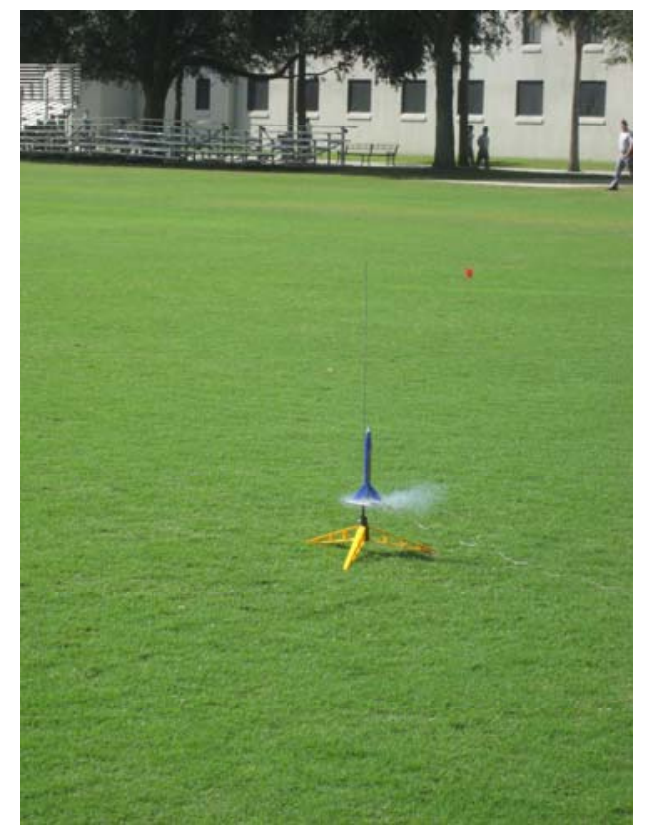

Figure 4. Rocket Launch

Civil Engineering. During one of the Engineering activity hours, the $4^{\text {th }}$ and $5^{\text {th }}$ graders investigated the different sub-disciplines of civil engineering. The focus was to draw out of the students where they have seen or experienced the different sub-disciplines, what are potential future challenges within these sub-disciplines, and the awesome potential that each student has as an engineer. The faculty then led the students through a variety of active learning activities designed to educate, challenge and inspire students including: Mechanics of Materials: Tensile testing a steel sample until failure (guess load it will break, how it will break, and uses of steel) or crushing concrete (Figures 5 and 6); Fluid Mechanics: Open channel follow demonstration with moving hydraulic jump, how it applies to stream and rivers they may have experienced, and the dangers of low dams (Figure 7); Geotechnical Engineering: Seismic demonstration with JellO soil and toothpick/marshmallow structures to demonstrate how the soil moves, why it moves along fault lines, and the damage that occurs along fault lines such as the one in South Carolina, California, Missouri, etc. The hour concluded with a tour of the facilities. ${ }^{9}$ 


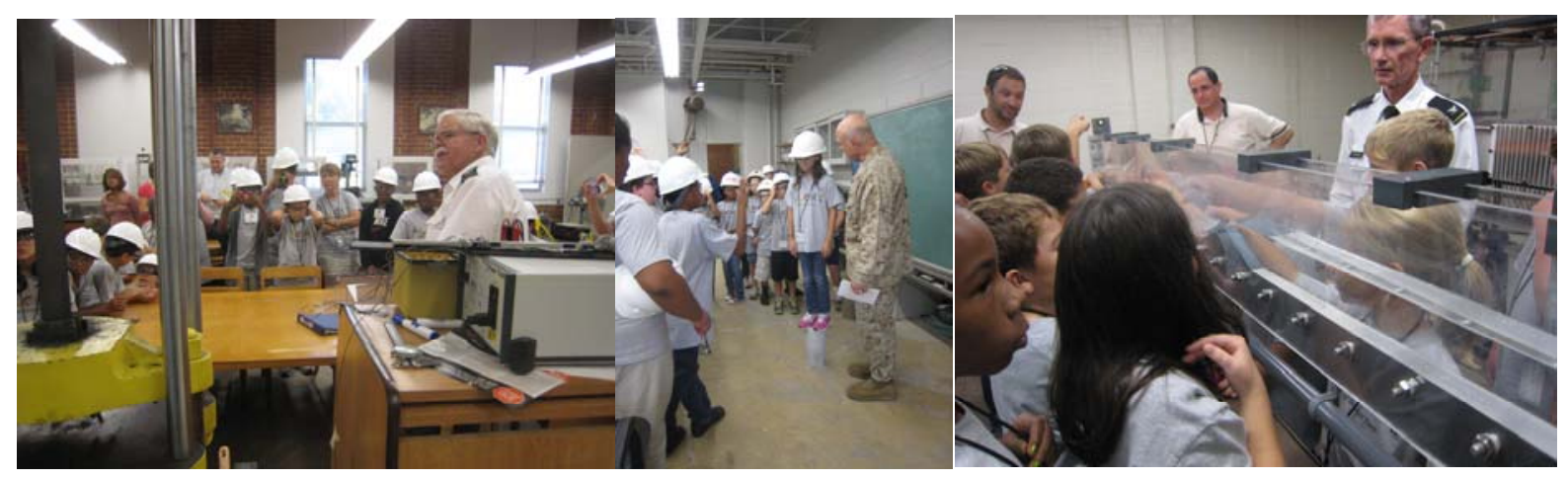

Figure 5-7. Concrete testing, steel testing and the flume.

Electrical Engineering. During the second hour of the Engineering activity hours, the $4^{\text {th }}$ and $5^{\text {th }}$ graders investigated sub-disciplines of electrical engineering. The focus was to draw out of the students where they have seen or experienced the different sub-disciplines, what are potential future challenges within these sub-disciplines, and the potential that each student has as an engineer. The faculty then led the students through a variety of active learning activities designed to educate, challenge and inspire students including: 1) What do your ears see? (Figure 8) Our eyes see light, but what do our ears "see”? They see small changes in the air caused by noises. This device will let you see those small changes in the air that your ear "sees" when someone says your name. This signal is sent to your brain which recognizes it as your name. How to use it: Press the "Single" button in the upper right; Clearly say your name into the microphone; The picture of your name will appear on the screen; If you would like to print out the waveform, press the "Quick Print” button. How it works: The microphone essentially acts like your ear - it converts the changes in the air into electrical signals using a device called a transducer. The Oscilloscope displays the electrical signal. The only thing we're missing is a brain to recognize this signal as your name! Things to try: Try saying your name different ways. Try it faster and slower. Let someone else say your name - compare it to how it looked when you said it. Try to pick out the individual syllables in your name. 2) Alert Radio! We use radio waves every day! They allow us to listen to music in our cars, talk on our cell phones, even to talk to satellites and astronauts! Transmitters take sound and change it into electrical signals that can be transmitted through the air over long distances. A radio detects these signals and turns them back into sound. How to use it: Have a classmate get near the radio on the other side of the room. Turn the large dial on the left side of the oscillator and listen to the change from the radio. How it works: The oscillator produces an audible "warble tone" which sounds like a police siren. The function generator it is connected to changes the signal into what is called an "amplitude modulated" (or AM) signal. The wire attached to the function generator acts as an antenna to send the AM signal through the air. The radio picks up the AM signal and turns it back into sound. Things to try: Try holding the end of the wire - you're now part of the antenna! Try moving around and changing positions while you are an antenna - does it change the sound? 3) Light Spiders! (Figure 9) Robots, and all living things, use their senses to react to their environment. When you turn a light on, a cockroach will scurry to the dark. These spiders will do the opposite! When they see light, 
they will try to go towards it. How to use it: You and a classmate each get a robot. Choose another classmate to be the referee. Turn your robots on - the lights should blink. Place each robot just behind the starting line, one in each lane. Use your flashlights to "drive” the robots. You must stay in your lane. The first one to cross the finish line wins! How it works: The robot has two electronic "eyes" that sense light. The robot has electronics to know which sensor is getting more light. The electronics control the motors on the robots to get it to move forward and turn towards the "eye" with the most light. 4) Lego Baseball! (Figure 10) Robots can be used to perform repetitive and boring tasks. They are used to help build cars and computers. You can even buy one to vacuum your carpets for you. Can they be used to play sports? How to use it: Place the baseball on the T on the metal "bump." Place the robot on home plate. Press the orange button to run the program. How it works: The robot is programmed to go forward, hit the ball and start heading towards first base. The robot has an electronic "eye" that sees the black line. Every time it sees the black line or a base, it turns left until it no longer sees the line. Things to try: Try moving the sensor. How does that affect the robot's performance? Try the different wheel sizes on the robot. Does it work as well? ${ }^{10}$

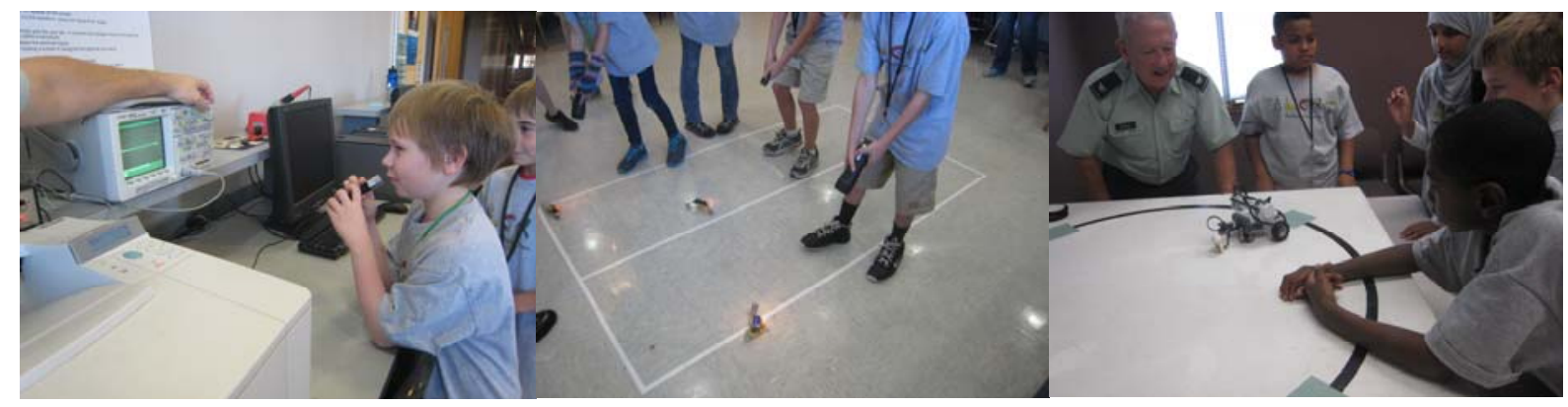

Figures 8-10. What do your ears see? Spider bots. Lego Baseball!

STEM Center. During the hour of the STEM Center activity, the $4^{\text {th }}$ and $5^{\text {th }}$ graders investigated how a trebuchet works. The Center has trebuchet kits it uses with elementary teams during EWeek. The students break into teams of 5, assemble the trebuchet, then they experiment with the number of marbles within the counter-balance box and how far the rubber ball is thrown. A discussion of the mechanics of the trebuchet occurs naturally as the students have questions. Near the end of the hour each team tries to hit the target at a prescribed distance. ${ }^{11}$

Admissions Tour. During the hour of the admissions tour, the $4^{\text {th }}$ and $5^{\text {th }}$ graders are treated just like applicants visiting the campus to determine if they would like to attend The Citadel. The school history, student activities, mascot, majors within each building, etc. are mentioned which lead to numerous questions about college in general from these very bright $4^{\text {th }}$ and $5^{\text {th }}$ graders. The idea is to set the seeds about college and the STEM majors in particular that are on campus. These discussions tied to the activities within the other hours paints a clearer picture of what college is and why they might want to strive to attend, especially in a STEM field. 


\section{Activities in the Richland District 2 Gifted and Talented Elementary Pull-out Program (ALERT)}

The elementary teachers take numerous pictures of their students completing activities on campus. These pictures allow a seamless incorporation into lessons and transition into mathematics and science lessons. Examples of mathematics and science problems and projects back in school that have been influenced by the field trip to The Citadel include: the incorporation of more hands-on problem solving by the students themselves, i.e. Leonardo's Arched Bridge (RAFT Activity), Oil Spill Challenge, construction of bridges to meet weightbearing and span requirements, mathematics patterns and problem solving steps mathematics classes.

For Leonardo's Arched Bridge (Figures 11-12), students were assigned to teams of 2-3 and provided with 18 paint sticks (provided by Home Depot, etc.). Using ONLY these materials (no tape, string, etc.) students were challenged to create a bridge. Bridges were tested using student journals as weights. ${ }^{12}$

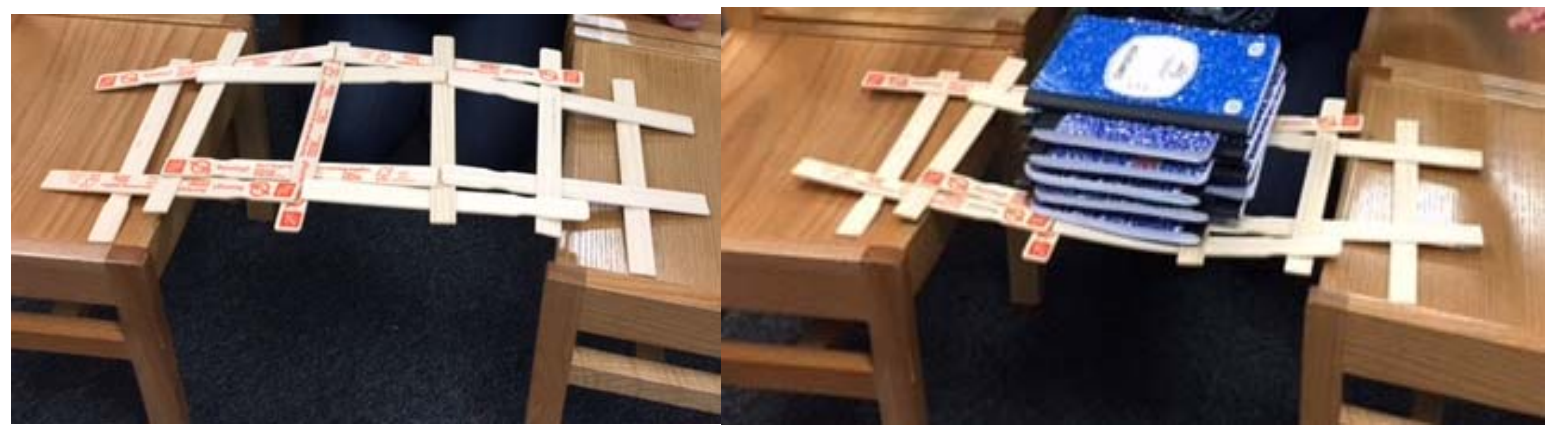

Figure 11-12. Leonardo’s Arched Bridge design with paint sticks.

The Oil Spill Challenge grew out of all the news surrounding the BP Oil Spill. After viewing you-tube videos on the topic and completing a graphic organizer about the disaster, students experimented with potential cleaning items. In groups of 3 or 4 they worked together (experimented) as Environmental Engineers to see how effective various materials are at cleaning up/absorbing oil in water. They were supplied with trays that had water and oil in them and a selection of "cleaning" materials: hay, coffee filters, Dawn soap, hair clippings, and cotton balls. Students created a chart to list predictions about each item's effectiveness using a scale of $0-5$. (0 being not effective and 5 being the most effective).

The teachers and students are already passionate about mathematics and science. However, there have been a number of curriculum adjustments that have taken advantage of the experiences from the field trip to The Citadel. Some of these curriculum adjustments are: increased hands-on problem solving elements, greater incorporation of movement activities such as to replicate the forces on bridges, challenges such as Venn Perplexers designed to help students make connections between the various elements of science, technology, mathematics, engineering and 
arts, and greater focus on the Design Process through activities such as Rube Goldberg challenges and the Dyson Project. ${ }^{13}$ One STEM related hands-on project is an invention project. Students are challenged to find a solution to a problem by creating/designing something that will make someone's life easier.

\section{Results}

The statement: “Assessment of curriculum changes based on the field trip, student reflective essays, and future attendance at middle and high school STEM magnets will demonstrate the importance of collaboration between universities and elementary and middle school programs (especially STEM focused programs) on engagement with STEM disciplines in the future,” was presented as part of the abstract. These visits to The Citadel every other year have been occurring since 2004 (approximately over 90\% of the gifted and talented students participate in the engineering field trip) and The Citadel faculty this past year began to ask about the actual success of this program. They were beginning to question the validity of the time and cost investment as research requirements for tenure have been steadily increasing (this was the sixth year to support six visits of approximately 100 students each). It was reasonable to assume that there were program requirements for ALERT to track the future activities, middle and high schools attended, and college majors of these gifted and talented pull-out students exposed to STEM through field trips and curriculum engagement each year. It was also assumed that preand post-test surveys were being conducted to demonstrate the value of the field trips to the education of the students as well as possibly tracking the students to validate increasing the number of students entering STEM fields. However, upon closer investigation through the submission of this paper, the program is successful based solely on student mathematics and science scores and successful activities outside and inside of the classroom to engage the students on possible STEM careers through appropriately modified and enhanced mathematics and science activities. From all their required measures, they are extremely successful.

A review of the literature points to many successful outreach programs through the use of preand post-surveys of student attitudes toward STEM careers and assessment of student grades and skills, and the ALERT anecdotal data aligns closely with these studies. ${ }^{14,15,16,17,18,19,20}$ The ALERT program plans to begin the use of pre- and post-surveys (no one has asked before and it is not required to show success as part of the talented and gifted program). However, there is almost no data (almost no tracking of students) to show how STEM programs within elementary and middle schools actually leads to more students entering STEM fields after graduation from high school. Each project shows improvement in skills or attitudes, but literally none track a student from no STEM interest, to having some interest, to actually going to college or into a STEM field after high school graduation. Through discussions with recent applicants for an open STEM Director position as well as discussions with the SC STEM Collaborative, the biggest difficulty for many STEM programs and outreach programs is the tracking of students once they leave a given STEM program as well as the consistency and quality of STEM engagement as the students continue through their middle and high school programs. 
The ALERT program has only been able to ascertain their success through two external sources: where the talented and gifted students attend middle school in Table 1 and how many take engineering courses in the local high schools. Please note that even though the students are talented and gifted and were exposed to an integrated STEM focused mathematics and science curriculum as part of a pullout program, many are in magnet schools that have a non-STEM focus. One measure of success is the percentage of students in TLC and SIDI.

Table 1. Magnet programs and percent gifted and talented attending.

\begin{tabular}{|l|l|}
\hline Name of Magnet Program & \% Gifted and Talented \\
\hline TLC & $78.9 \%$ - high achieving \\
\hline TWO & $35.4 \%$ - single gender \\
\hline LAW & $48.4 \%$ - leadership \\
\hline Inc. & $68.2 \%$ - business /economics \\
\hline ZooBot & $32.0 \%$ - environment \\
\hline Get Fit & $36.4 \%$ - sports marketing \\
\hline SIDI & $47.1 \%$ - STEM \\
\hline
\end{tabular}

GetFit: "The goals of The Academy of Exercise Physiology and Sports Medicine at Summit Parkway Middle School are to prepare our students to pursue careers related to the support of healthy lifestyles and to guide students in becoming role models for exemplary health and wellness. Students study advanced anatomy and physiology, the mechanics of movement, the physics of motion, and the historical implications of health and fitness.”

Inc. at Kelly Mill Middle School is a "district-wide magnet program with an emphasis on business and economics.”

LAW: Leadership Academy at Wright (E.L.Wright Middle School)

TLC: The Learning Collaborative at Dent Middle School. "TLC serves high-achieving and highly motivated students by immersing them in a rigorous, intellectually stimulating academic environment. The foundation of TLC is the emphasis on higher order thinking skills through the integration of the academic disciplines."

ZooBot: the School of Zoological and Botanical Studies at Longleaf Middle School.

"The ZooBot magnet program provides opportunities for students to explore the natural world, develop an appreciation and respect for living things and the environment, and make a difference for future generations.” 
SIDI: “The STEM Institute of Design and Innovation (SIDI) at Summit Parkway Middle School is a magnet program focused on science, technology, engineering, and math education for up to 80 students per grade level. This program provides students the opportunity to explore various science and mathematics strands from an engineering and technology standpoint. There is also a strong focus on careers in these areas of industry”.

\section{TWO: “Single Gender Program at Dent Middle School”}

All of the descriptions of the magnets are quoted from the Richland School District website. ${ }^{21}$

In the past two years (2013-2014 and 2014-2015), Richland Two Gifted and Talented Program has had 171 high school Gifted and Talented (State Identified gifted and talented) students take at least one engineering course. That is about $12 \%$ of the gifted and talented high school population. What constitutes an engineering course varies considerably from a drafting class to a Project Lead The Way course with a First Robotics entry to a design course determining the requirements for a new development, car or airplane. The fact that in 2004 and 2006 the students spent 2 hours with the engineering faculty and students at The Citadel and the other half with the engineers designing and building the Ravenal Bridge (Year A) may have affected the number of students in at least one engineering course. Only a future long-term assessment of the number of gifted and talented students taking at least one engineering course as well as type of engineering course will determine if the amount and type of engineering exposure then and/or the exposure with Architectural (Humanities Habitat) and Sustainable Living (now Year B) has had the desired effect. The architects offer a Kid in Architecture day that is only open up to ALERT students and occurs on a Saturday. Here is an example of verbiage that supports high school lead STEM activities:

“The DISCOVERY Program at Spring Valley High School is a four-year Honors/AP program designed for students with motivation, interest, aptitude and commitment to academic excellence. Student participants investigate both theory and application over a broad range of academics and engage in, under the guidance of a school or community mentor, individualized laboratory-based research in a specific area of their own interest. Honors and Advanced Placement courses are offered in all academic areas, with distinctive opportunities in the fields of science and mathematics. Program participants also explore Honors/AP level courses in literature and history with Honors/AP level options in drama, art, language, and music."22

So is the cost and time spent on the field trips worth this level of participation in these two middle schools or in engineering classified high school courses? The ALERT program would say yes. The faculty at The Citadel is not so sure.

\section{Assessment by Richland School District 2}

The students, but especially the parents (about 10 percent of the parents attend the field trip as well), cite the integration of field trips into the curriculum to include the visit to The Citadel as a 
major reason they have sought to continue their child's education at a STEM focused school. Many often mentioned to the author and the elementary school teachers that a key factor is meeting, learning, and being inspired by college age students who are also passionate about STEM topics. Their young children can see themselves in the future studying about mathematics, science, and engineering. These subtle, short connections cannot be under-estimated as to the influence they have on students sticking with STEM courses even when they become difficult. However, is one encounter enough or must the students engage each and every year with STEM activities that inspire them? Tracking and surveying students long term is required to more fully understand cause and effect.

Even though the teachers do not have access to assessment data to show the long-term benefit of the program, they have and continue to observe many changes in their students. Since they are already the gifted and talented students and over $90 \%$ of the students participate each year in the field trips, they are not able to disaggregate information from test data. However, they can note anecdotally from parents whose children have gone on to study STEM fields in college and the change in student understanding, vocabulary, and connections are evident after each field trip.

The Year A (visit The Citadel) and Year B (Architecture and Sustainable Living - Humanities Habitat) are synergistic and provide students multiple year exposure to common concepts and themes. With Humanities Habitat, there is a connection to earthquakes which has been simulated in the Civil Engineering Department as well as the department has used Dr. Seuss' The Lorax to help students see the connection/impact engineering has on the environment. Additionally, there have been presentations on preserving the outside of a building while the inside has been completely remodeled.

The biggest impact is on the attitude of the gifted and talented students. Students were exposed to a variety of STEM career opportunities that were observed and highlighted during the visit. Most students thoroughly enjoyed the view into college life and interacting with college age students. Most are from the inner city and many of the young adults they know did not attend college. Weeks and sometimes months later, students will make a comment in class about something they had seen, an interest in attending The Citadel, and an interest in studying engineering or another STEM major. If one student is talking about it, others are listening and thinking about it as well. A very positive impact was when engineering students from their area took time out of their busy day to drop in and say "hi" and "high five" them. This is not a goal of the project, but the experience of visiting a college that draws students from their schools is a goal of the project.

The STEM activities at The Citadel allow the students to meet engineers - both faculty and students at the university level. Many talk about how they liked mathematics and science in elementary through high school, but then had to work hard in mathematics and science in college in order to stay an engineer. The activities help the students develop an appreciation in a practical real-world setting about the interconnectedness of disciplines such as mathematics, 
science (Physics and Chemistry) and engineering. An example is seeing how mathematics is used to describe various water flows and situations that are being demonstrated right in front of them. The experience adds a relevance to learning algebra (and later geometry, trigonometry, and calculus) in school when otherwise it might appear irrelevant to some or just another academic subject I have take. As noted above, for many this is there first visit to a university setting and the experience helps many after meeting college students that attending a university is a viable option for their future.

It is easy to see from above that Richland School District 2 would not be as effective without the state/county funding ALERT, the student funded field trips and support of STEM programs at the university level. Interestingly, the University within their own county will not make the time for these activities based on research and teaching demands taking priority. The Citadel spends time after every visit discussing if they also have the time and resources to continue supporting six visits during a semester - all for only one school district. Without a doubt, the impact on the elementary students is profound based on the teacher's anecdotal comments above and the thank you notes sent by each student. Each student took something completely different away from the visit: how to control robots, what power is required to get the right amount of lift with a rocket, making mathematics problems fun and showing them they already know something about the next level of math (algebra), what really causes the different colors when completing the dancing gummies experiment, the importance of counter weights for distance in a trebuchet, how a low overflowing dam in a river can create a wonderful area for boating and swimming, but also an unexpected danger right below the dam where many boaters and swimmers find themselves unknowingly trapped, seeing inside college classrooms and labs, visiting and learning with college-age role models in STEM areas, seeing college campus life, etc. ${ }^{23}$

Unfortunately, like many STEM focused programs, it is easy to see the positive change in interest, focus, and attitudes of students after a visit (why teachers are so excited about this field trip even though it requires two hours of travel each way) and can list the changes in how content is covered (as mentioned above) when these elementary teachers see how important are physical model $^{24,25}$ within STEM education. The truly hard part is tracking students all the way to entering a STEM field that have experienced these truly amazing STEM activities either on field trips, competitions during E-week (robotics, bridge, trebuchet, etc.), when attending a STEM school or being part of STEM pull-out as is done with these 19 elementary schools. Are these students receiving additional STEM engagement opportunities in middle and high school? As we can see above, they do not receive additional STEM focused activities if they do not attend the right magnet school. How many actually matriculate into a STEM job after graduation or into a STEM major in college? How do numbers compare with this school's efforts as well as when students are able to experience STEM activities throughout middle and high school when a school district has ensured STEM focused activities each year from elementary through high school? Elementary schools and probably most schools are not resourced nor required to track students' progression to STEM fields after high school beyond what is provided above. If we are 
to improve the matriculation of female and minorities into STEM fields, more needs to be done beyond what is done in elementary school. Each group of students attending the field trip to The Citadel was over $50 \%$ female and over $25 \%$ minority. Programs that are being used in college are limited because too few females and minorities are interested in STEM careers by the time they reach high school and for sure college. ${ }^{26}$

\section{THE CITADEL Concerns:}

When taking time out of the middle of the college day, morning 10 - 12 AM and afternoon 1-3 $\mathrm{PM}$, the impact on heavily constrained schedules and resources can be daunting. Elementary students take these field trips during the week and during the day. The Citadel is two hours away from Richland County leaving the sweet part of the academic day as the best time for their field trip. Considering there are approximately $6004^{\text {th }}$ and $5^{\text {th }}$ graders at these 19 elementary schools pulling out for STEM activities, the result is 6 visits to The Citadel.

Not every activity requires huge set-up or reset-up, but most take time prior to the visit to prepare the activity. The most exciting types of activities normally require the most pre-set-up and costs. The rocket examples in Physics will be highlighted. There were roughly 150 out of the 600 students who participated based on faculty, space, and timing conflicts. This number requires approximately that number of rocket engines and approximately 40 model rockets.

Approximately 10 were given as prizes and 15 were damaged after multiple uses to the point that they were discarded. Most of the cost of models and engines was handled by The Citadel STEM Center, but launch pads (3) and electric launch switches (3) were purchased by the Physics Department out of department operating funds (approximately $\$ 170$ ). These sessions were extremely fun and exciting for the students, but an enormous burden on the faculty (six times, right in the middle of the college day) with the construction and reconstruction of the rocket models, the lesson demonstration set up and take down, the launch for each student, and the cleanup. One professor participated during every event based on his schedule, one adjunct helped with all but one time slot, and several other faculty helped when they could. Many professors had physics laboratories which conflicted with the 2 to 3 PM "launch

window". Fortunately, and desired by the elementary students, 3 or 4 college-age students could assist during each scheduled time slot.

The opposite end of the spectrum is the electrical engineering activities which required minimal set-up since the equipment is part of existing laboratories and the antennae and Lego baseball were set-up in the department conference room for the duration (a month).

Another issue at many universities is how to give credit for these types of activities when faculty plates are already too full with department, college, university, and national service. Additionally the actual dates of student visits can limit the availability of faculty, laboratories, and space to host these types of activities. This year the use of the trebuchet with the STEM Center and the 
Admissions tours were added to offset times when Mathematics, Chemistry, Biology, and Physics faculty were not available to fill the time slots not being covered by engineering. Many faculty do not see the "bang for the buck" when it comes to elementary and middle school activities. The faculty want to focus more on the high school level REUs that may actually lead to research funds, scholarship and future students. If these college type STEM activities enhance what is being covered in elementary school STEM programs, should states also provide funding to universities willing to participate each year? When just faculty salary is considered, the cost was well over $\$ 15,000$ (not including benefits) in what some faculty label as unproductive, especially when longitudinal data is so limited on the effect.

\section{Conclusions}

As one department head stated: "Great fun but costly in time and money. One or two such meetings would be fine, but six in a single semester is too much." Once faculty are involved with these STEM focused elementary and middle school students, they see the student excitement and truly enjoy themselves. Every faculty member visited with felt the activities and time spent with the students enriched their lives and could see that this investment in time (and money) could make the difference in more young people entering STEM fields after high school.

However, there are a number of questions that must be answered and actions to initiate if these activities (and costs) are to continue. Questions: Are these types of activities part of the University mission? Should they be? Can assistant and some associate professors afford the time away from the critical tasks associated with tenure and promotion to participate, considering they are some of the most energetic and creative in developing impressive activities? If it is important, then the culture of each department needs to be adjusted to include these activities as part of the service mission and funding streams must be identified to cover the cost of expendables mentioned above.

Actions: If the field trips are to continue and the costs to be acceptable, there needs to be a more scientific approach to data collection to include pre- and post-surveys of the students (start and end of $4^{\text {th }}$ and $5^{\text {th }}$ grade and before and after field trips to capture changes in attitudes), quality review on work done when tied to things they have seen on a trip versus an item they have not seen, capturing of curriculum changes based on the inspiration the teachers received as part of the trip, etc. Somehow School districts need to enlist the support of the Superintendent to complete longitudinal tracking of students who have been involved in STEM focused activities to include yearly surveys to determine if they are continuing on the path toward a STEM field. Similar levels of activity from elementary through high school must be available each year to provide the motivation and support these students need to maintain the attitudes and interest in STEM. Right now, the torch is being carried by parents who have the opportunity to apply for STEM focused middle and high school as noted above. However, there is a decrease in support at some of those schools who have not landed the next grant or the key teacher has retired, moved, or scheduling is an issue. The literature review shows activities being employed in 
elementary, middle and high school are having a huge impact on the attitudes and interest in STEM fields. However, the sporadic insertion of these activities such as in the $4^{\text {th }}$ and $5^{\text {th }}$ grades, but no support network to continue the STEM engagement after they leave $5^{\text {th }}$ grade begs the question on the validity of the expense in time and money. If the rigorous data collection and assessment associated with yearly STEM activities is not available from elementary to high school, then the true impact of STEM related K-12 activities will not support the rigorous educational research projects that would allow faculty to receive full credit for their time and effort.

The author's firsthand experience over multiple visits to The Citadel of the enthusiasm of the students, parents and teachers alike and the evolution to problem-based activities that incorporate many hands-on physical models makes these service-related activities worth every dollar, especially when considering where these children are coming from (poor intercity areas). It is important as the faculty consider the long-term value of these activities that a rigorous research agenda is established and monitored closely before any such visit/activity start. These visits were started prior to any of the current program leadership being in place and now adding these requirements is more difficult when the elementary schools have already demonstrated to their districts success based on requirements that are not as rigorous (noted above).

This experience with ALERT has highlighted the importance of being strategically vigilant to ensure most service activities (such as this) tie succinctly back to research priorities and needs of the faculty while also highlighting the accomplishment of service outreach the university desires.

Acknowledgements:

The teachers from the following schools work with the talented and gifted students being pulled out for STEM focused activities at The Citadel and provided input and insight for the paper. Since they are not members of ASEE, their assistance and input is being acknowledged here. Note: many work at multiple schools.

Anna Alexander: Lake Carolina Elementary Upper Campus and Sandlapper Elementary

Dr. Mary Fanning: Langford Elementary and Windsor Elementary

Pamela Johnson: Bridge Creek Elementary and Lonnie B. Nelson Elementary

Sheri Barfield: Bookman Road Elementary

Amy Lytle: Rice Creek Elementary

Kevin Durden: Lake Carolina Elementary Upper Campus

Jeanne Blackburn: Bethel Hanberry Elementary and Forest Lake Elementary

Brooke Ross: L.W. Conder Elementary, Killian Elementary, and Joseph Keels Elementary 


\section{Lydia Hutto: Pontiac Elementary}

Becky Watkins: Round Top Elementary

\section{Bibliography}

1. http://wandohigh.ccsdschools.com/schoolsofstudy/mse. Site visited 1 Feb 2015

2. https://www.richland2.org/Departments/Academics/Pages/ALERT(GiftedandTalented).aspx. Site visited 1 Feb 2015.

3. Thank you note form ALERT student October 2014.

4. https://www.youtube.com/watch?v=Wou1Udu_vr8. Site visited 1 Feb 2015. Activities and content provided by the Biology Department.

5. http://www.pbs.org/wgbh/nova/evolution/guess-embryo.html. Site visited 1 Feb 2015. Activities and content provided by Biology Department.

6. http://chemistry.about.com/od/chemistrydemonstrations/ht/gummibear.htm. Site visited 1 Feb 2015. Activities and content provided by Chemistry Department.

7. PowerPoint Presentation by Stephen D. THE CITADELX as the THE CITADEL, ALERT visit October 2014. Activities and content provided by Mathematics Department.

8. Activities and content provided by the Physics Department.

9. Activities and content provided by the Civil Engineering Department.

10. Activities and content provided by the Electrical Engineering Department.

11. Activities and content provided by the STEM Center.

12. http://www.raftbayarea.org/readpdf?isid=580. Site visited 1 Feb 2015.

13. http://www.jamesdysonfoundation.com/educators/2nd-6th-grade/. Site visited 1 Feb 2015.

14. Parry, E., "Making Elementary Engineering Work: Partnerships and Practice - North Carolina State,” Proceedings ASEE Annual Conference, 2011.

15. Wiebe, E., Faber, M., Corn, J., Collins, T., Unfried, A., Townsend, L. “A Large-scale Survey of K-12 Students about STEM: Implications for Engineering Curriculum Development and Outreach Efforts (Research to Practice),” Proceedings ASEE Annual Conference, 2013

16. Nadelson, L., Callahan, J. "Where do We Go from Here? Conversations with K-6 Principals Following three Years of Engineering Education Professional Development for Their Faculty,” Proceedings ASEE Annual Conference, 2014

17. Ernst, J., Bottomley, L., Parry, E., “Term Analysis of an Elementary Engineering Design Approach,” Proceedings ASEE Annual Conference, 2012

18. Lundstrom, K., Moskal, B., "Measuring the Impact of an Elementary School Outreach Program on Student's Attitudes toward Mathematics and Science,” Proceedings ASEE Annual Conference, 2012

19. Brophy, S., Klein, S., Portsmore, M., Rogers, C., “Advancing Engineering Education in P-12 Classrooms,” Journal of Engineering Education, VOL 97, Issue 3, pages 369-387, July 2008

20. Tran, N., Nathan, M., "Pre-College Engineering Studies: An Investigation of the Relationship Between Precollege Engineering Studies and Student Achievement in Science and Mathematics,” Journal of Engineering Education, VOL 99, Issue 2, pages 143-157, April 2010.

21. For further information about magnet programs you can visit the district website at: https://www.richland2.org/Departments/TeachingLearning/Pages/MiddleSchoolMagnetProgramsCenters.as pX

22. http://www.ask.com/wiki/Spring_Valley_High_School_(South_Carolina)?qsrc=3044\&lang=en. Site visited 1 Feb 2015.

23. Welch, R. W., "How Just in Time Learning Should Become the Norm!” Proceedings of the American Society for Engineering Education Annual Conference, Louisville, KY, 20-23 June, 2010. 
24. Welch, R.W., and Klosky, J.L., "An Online Database and User Community for Physical Models in the Engineering Classroom,” ASEE On-Line Journal, 2007. (No presentation).

25. Estes, A.C., Welch, R.W., Ressler, S.J., “The ExCEEd Teaching Model,” Teaching Lessons Learned. Journal of Professional Issues in Engineering Education and Practice, ASCE 131 (3), July 2005.

26. Davis, W.J., Bower, K.C., Welch, R.W., "Enhancing Undergraduate Civil Engineering Opportunities for Minority, Females, and Socioeconomically Disadvantaged Students," Proceedings of the 2014 American Society of Engineering Education Annual Conference and Exposition, Indianapolis, IN, June 2014. 